\title{
PRODUÇÃO DO ESPAÇO URBANO PELOS HOMENS ORDINÁRIOS: ANTROPOLOGIA DE DOIS MICRO-ESPAÇOS NA CIDADE DE SALVADOR
}

\author{
Urpi Montoya Uriarte ${ }^{1}$ \\ "A luta de classes, hoje, mais do que nunca, se lê no espaço" \\ (Lefebvre, 2000: 68)
}

\section{Antropologia dos espaços urbanos e de sua produção ${ }^{2}$}

Comecemos localizando os campos dentro dos quais estão contidas as reflexões deste artigo. Trata-se, em primeiro lugar, de reflexões antropológicas, pois emanam de um ímpeto pela "busca por um entendimento generoso, comparativo e, no entanto, crítico sobre o ser humano; um saber no mundo que habitamos" (Ingold, 2008: 69).

Dentro da antropologia, é a trilha da antropologia urbana que percorremos, interessados como estamos em pessoas em contextos urbanos. Contudo, o nosso interesse abarca tanto as pessoas quanto os espaços específicos que elas constroem. Caberiam, então, estas reflexões, na subárea denominada antropologia do espaço?

Segundo Ségaud (2010), a antropologia do espaço se interessa pelo espaço vivido, pela forma como os usuários-habitantes-ocupantes vivenciam seus espaços; porém, como bem apontou Biase (2012), esta antropologia pouco tem dialogado com a Antropologia urbana e com a produção dos outros campos de conhecimento, além de ter se limitado a enumerar e descrever os variados significados atribuídos a aspectos espaciais em diversas culturas, tais como a marroquina, a japonesa, a francesa, etc.

Como chamar, então, a área em que se encontraria um estudo sobre produção de espaços na cidade feitos por pessoas comuns e não por forças abstratas como o mercado ou o capital imobiliário? Proponho chamá-la de antropologia dos espaços urbanos. Nesta perspectiva, a cidade é considerada como uma constelação de múltiplos espaços heterogêneos que, encontram-se ora justapostos ora separados, sendo em ocasiões contraditórios entre si e, em outras, complementares. A cidade seria o conjunto, sempre em processo de se fazer, de agrupamentos com formas mais ou menos definidas. Estas formas são o resultado não da superfície, mas de trajetórias múltiplas que se entrecruzam e cujos resultados são imprevisíveis (Massey, 2012). Visto de outro

\footnotetext{
${ }^{1}$ Universidade Federal da Bahia, Brasil.

${ }^{2}$ Este artigo é uma versão modificada e ampliada do texto apresentado no GT 065 "Os estudos socioespaciais e a antropologia contemporânea: trajetórias, diálogos e cooperação", da $29^{\text {a }}$ Reunião Brasileira de Antropologia (Natal, agosto de 2014).
} 
ângulo, este trabalho pode se inserir, também, no que se chama hoje de antropologia $d a$ cidade, que, mais do que buscar descrever e entender a vida dos grupos urbanos na cidade, se preocupa com a forma como os citadinos - em sua condição alternada de usuários, moradores, transeuntes ou consumidores - fazem a cidade-constelação de espaços (Agier, 2011).

Se propomos uma antropologia dos espaços é imprescindível esclarecermos o que entendemos por espaço. A teoria social - em grande parte graças à contribuição de Henry Lefebvre, um autor central neste trabalho - deixou há um certo tempo de entender o espaço de forma simplista e superficial, como mero pano de fundo, palco, recipiente sem conteúdo ou meio vazio (Soja, 1993). Ou, então, como um produto acabado. O espaço está sempre sendo feito, porque ele é um conjunto de relações sociais - sempre dinâmicas - que se estabelecem numa materialidade (ou natureza primeira). Isto quer dizer que o espaço não é uma coisa, mas um conjunto de relações entre as coisas. Produzir espaço significa, portanto, colocar em relação coisas.

Na cidade, o capitalismo tem gerado a produção de espaços cada vez mais "lisos" ao colocar em relação coisas cada vez menos contrastantes. O objetivo, segundo Paola Jacques (2012), é apagar o dissenso, extrair da experiência o choque com a alteridade. Ao eliminar o aleatório por meio da técnica, dizia Milton Santos (1996), os espaços produzidos pelos homens que reproduzem o sistema capitalista são tratados como coisas, e não conjunto de relações entre as coisas. É fácil deduzir o porquê: apagar o conflito e a necessária negociação dos espaços usados torna simples e aprazível a vida dos que se beneficiam com a transformação da alteridade em desigualdade. Mas, o que as pessoas comuns, anônimas, pobres em sua grande maioria, fazem com os espaços lisos e racionais construídos pelo poder público ou o capital privado (ou sua combinação)? Essas pessoas, propunha Certeau em finais da década de 1970 (2009), usam, empregam, praticam esses espaços, mas não passivamente. Mediante "astúcias milenares", os "homens ordinários" não produzem novos produtos, mas "maneiras de empregar os produtos impostos" (p. 39). Apesar de reconhecer a importância que este autor teve em seu contexto - um no qual primavam os estudos sobre os dispositivos do poder e sua força para disciplinar e impor uma ideologia -, acreditamos que os "homens ordinários" não se limitam a usar diferentemente o que lhes é imposto, mas, também, produzem coisas e, principalmente, espaços novos. 
Daí o nosso interesse em pesquisar micro parcelas do real para encontrar nelas o possível. Estas micro-parcelas são espaços pequenos, muito menores do que um bairro, menores ainda do que uma rua. São micro-espaços construídos por "homens ordinários" em seu cotidiano, em suas relações com outros seres. São micro-espaços que promovem, por sua vez, outras relações. Sem mais preâmbulos, os micro-espaços dos quais falaremos são um beco residencial convertido em ponto de venda e a parte baixa de um morro, escavada e capinada para se transformar em um ponto de comércio de artigos de madeira ${ }^{3}$. Nas linhas que seguem, começarei apresentando pessoas e espaços para, em seguida, tecer três leituras a partir de alguns conceitos propostos pelo filósofo francês Henri Lefebvre. Da vasta obra deste autor, usarei apenas os textos em que a cidade ocupou um lugar central em sua reflexão, isto é, suas publicações no curto período que vai do final dos anos 1960 até inícios dos anos $1970^{4}$.

\section{O beco de Gerson}

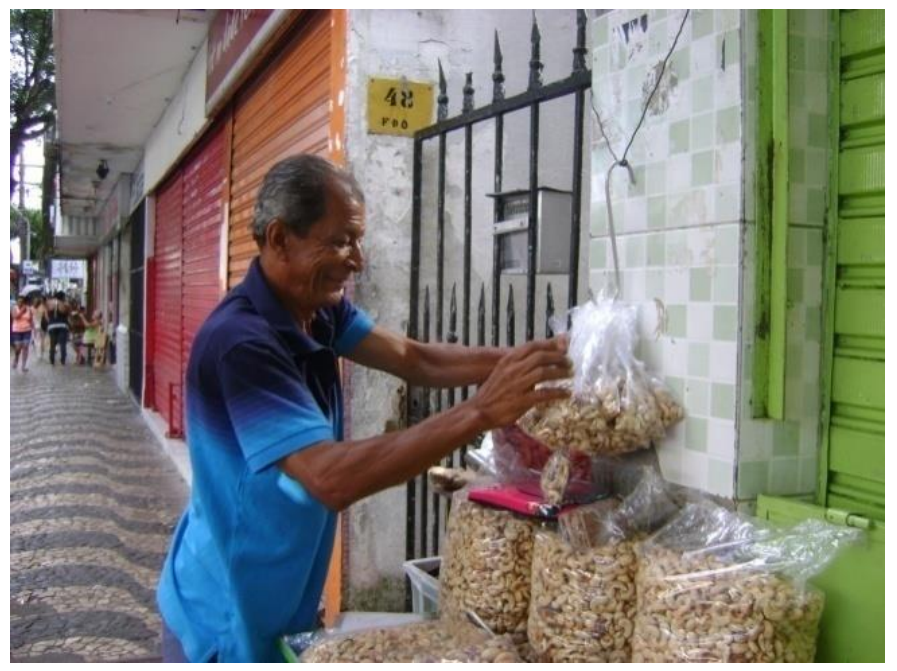

Fotografia de Urpi Montoya, 2013.

Este homem simpático, sorridente e bem-humorado chama-se Gerson. É vendedor de castanhas, camarão seco e quiabo na entrada de um beco sem nome, apenas

\footnotetext{
${ }^{3} \mathrm{O}$ meu encontro com estes micro-espaços aconteceu no transcurso de pesquisas diferentes, ambas localizadas na cidade de Salvador. O primeiro provém de um trabalho de campo iniciado em 2012 sobre os usos e transeuntes da Avenida Sete de Setembro (centro da cidade) e, o segundo, procede de uma pesquisa de campo que está ainda em seus estágios iniciais, sobre as formas de morar em Salvador.

${ }^{4}$ O direito à cidade (1968), Do rural ao urbano (1970), A revolução urbana (1970), O pensamento marxista e a cidade (1972), Espaço e política (O direito à cidade II) (1973), A produção do espaço (1974). No artigo "A rebelião do vivido. Henri Lefebvre no centro de Salvador" (inédito até o momento), faço uma recapitulação sobre a importância do pensamento de Lefebvre sobre a cidade.
} 
numerado (leia-se o algarismo 48), localizado na Rua do Forte de São Pedro, que fica entre o Campo Grande e a Avenida Sete de Setembro, dois espaços bastante movimentados do centro de Salvador.

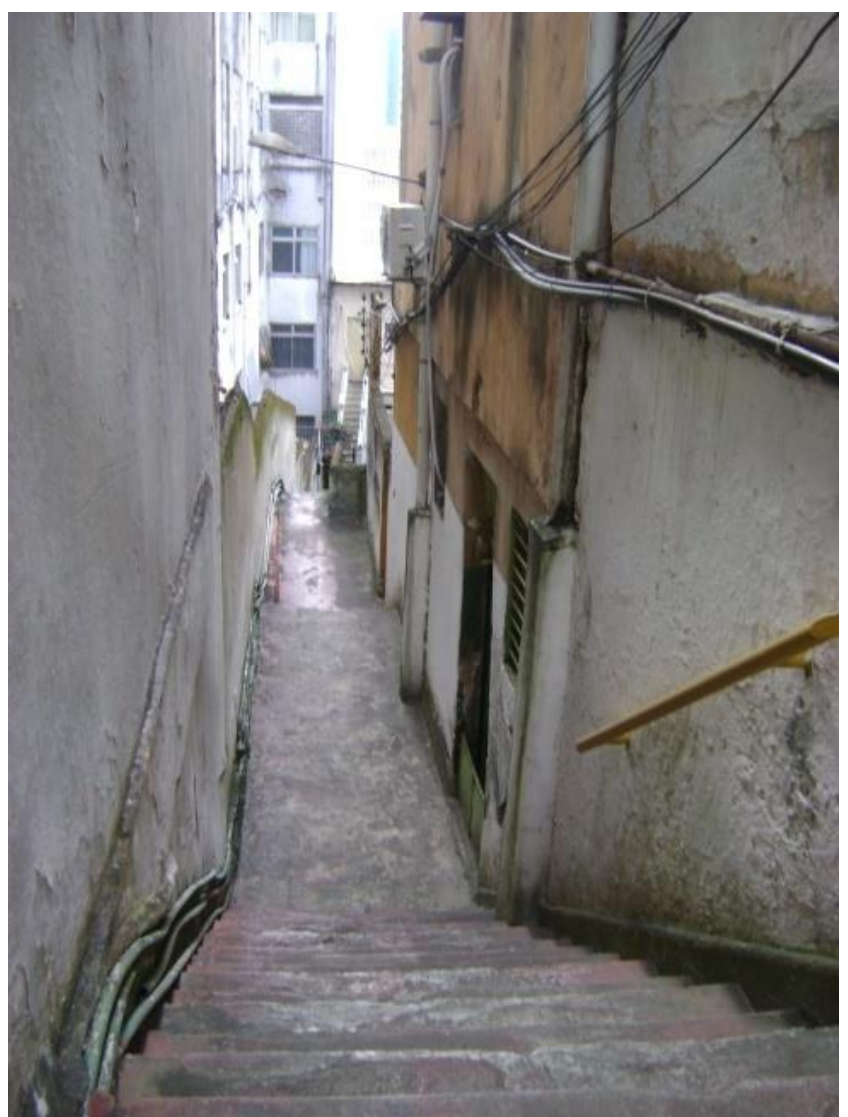

Fotografia de Urpi Montoya, 2013.

A porta de ferro do beco permite a passagem para um longo corredor em descida. Os primeiros 16 degraus separam o nível da rua de uma porta que dá acesso a um quarto, que pertence à loja de bijuterias, vizinha comercial de Gerson. Esse quarto serve de lugar de refeição para os vendedores dessa loja e também serve de depósito para as mercadorias de Gerson: uma caixa de plástico, algumas caixas de castanha e sua cadeira para sentar e passar o dia vendendo. 


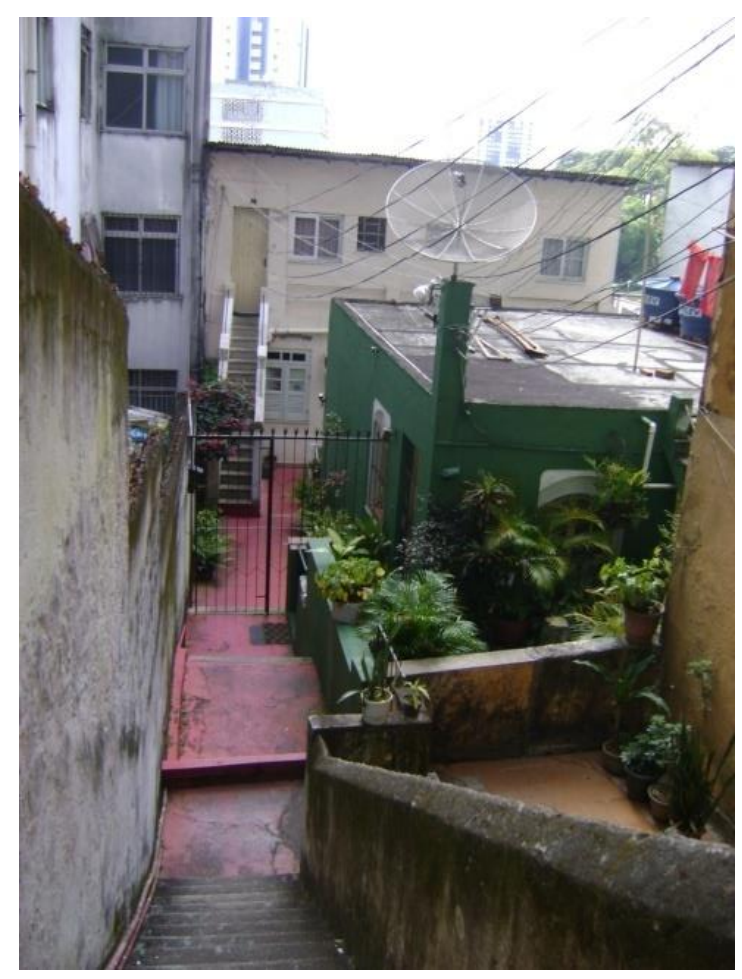

Fotografia de Urpi Montoya, 2013.

Este é o extremo oposto da porta, onde o beco vai parar após 3 conjuntos de degraus que descem. Vemos três residências: uma chamativa casa verde, uma casa térrea branca e uma outra, no primeiro andar. Nelas, moram várias pessoas que Gerson resume com o adjetivo "as véia". Tudo indica que são algumas senhoras as que cuidam do espaço coletivo e, portanto, dos usos do beco e da entrada do beco. Gerson só pode ter seu pequeno negócio de castanhas, camarão seco e quiabo porque tem a autorização "das véia" para ficar ali. As regras são claras: ele tem de ficar no reduzidíssimo espaço entre a porta do beco e a porta da loja de bijuterias.

Gerson trabalha nesse ponto de segunda a sábado. Ele acorda às $5 \mathrm{~h}$ da manhã. Chega à feira de São Joaquim às 5:30h. Compra o quiabo, o camarão, o gengibre (que não vende, dá de brinde para agradar às freguesas). Quando compra mais de um saco de quiabo, atendendo a encomendas da clientela, divide o carreto de 20 reais com Alfredo, seu colega de venda, que fica num outro beco, ali mesmo, na Rua do Forte de São Pedro, a poucos passos. Só que além de quiabos, Alfredo vende também bananas. Gerson chega todo dia às $7 \mathrm{~h}$ e fica até as $4 \mathrm{~h}$ da tarde. Aos sábados, fica só até $12 \mathrm{~h}$ ou $13 \mathrm{~h}$. 


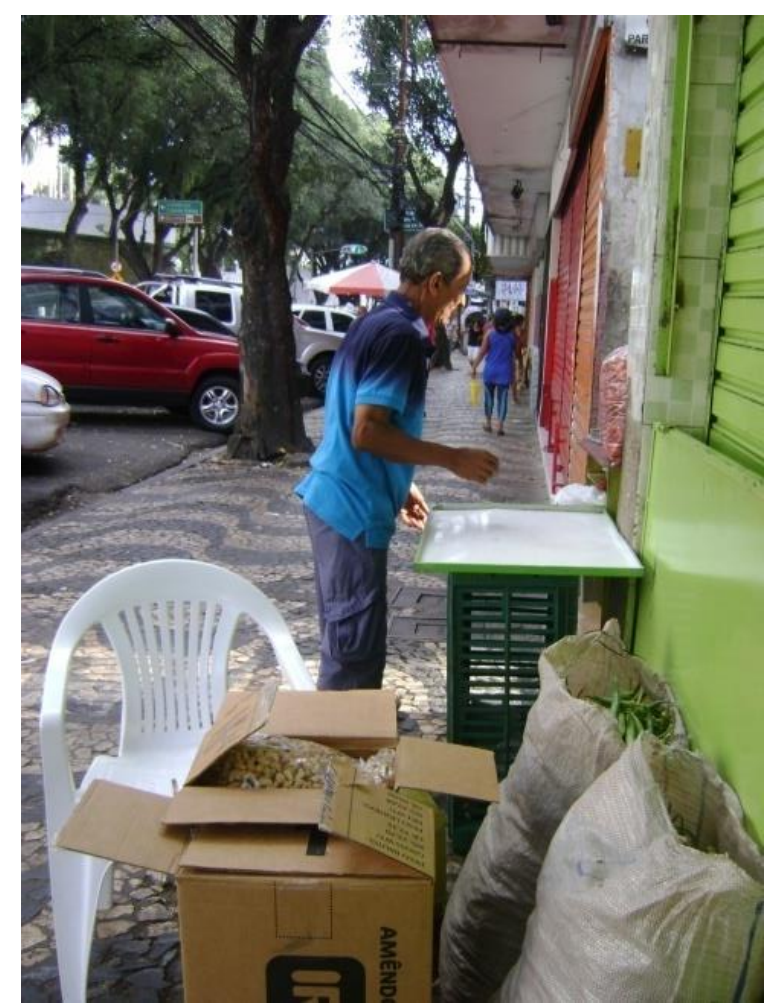

Fotografia de Urpi Montoya, 2013.

Chegando, toma seu cafezinho e alguma coisa comprada em São Joaquin para ele (e traz também de presente para as vendedoras da loja de bijuterias): beiju, bolo, carimã. Não tem pressa na arrumação, pois cedo há muito poucos fregueses. Enquanto arruma sua mercadoria, varre seu pedaço de rua, porque "nego faz assim ô: pega o camarão e joga aí" e ele gosta de tudo limpinho. Ele preza a limpeza: "troco de camisa todo dia", me comentou certa vez. Mas, em outra ocasião, deu mais um argumento para a varrida diária, "se deixar sujo as veia reclama".

Todo dia, pega suas caixas no depósito. São 16 degraus carregando $20 \mathrm{~kg}$ de manhã e no final da tarde. Seu posto é bastante simples: uma caixa de plástico duro e uma tábua por cima.

Há 40 anos que Gerson está nesse ramo. Na Rua do Forte de São Pedro, tem mais de 20. Conta que já teve pontos em diversos locais da rua. Seu ponto hoje é pequenininho. Mas já foi maior quando tinha muitos balaios e a rua era uma feira, onde o peixe se vendia e era tratado ali mesmo. A Prefeitura foi se impondo, proibindo o comércio de víveres, depois o comércio ambulante, deixando apenas os cadastrados. Gerson não se queixa: "É para o bem da cidade porque os balaios e essas coisas antigas tiram a estética da cidade". Além disso, acrescenta "se eu boto meu balaio aqui [num 
extremo da calçada] e aqui também [do outro extremo] vocês [pedestres] só tinham esse espaço aqui para passar”. Não fosse por isso, ele venderia mais coisas: maxixe, gilô, pimenta. "A freguesia lembra quando eu tinha mais coisas".

Disse-me que "tem três quaresmas que tiraram todo mundo. Só deixaram eu e Alfredo" (depoimento feito em 05/10/2013). Pergunto se têm licença de venda. "Não responde -, mas eles deixam ficar porque já conhecem a gente". Imagino que deve ser pela idade deles e o tempo que estão ali, além de ocuparem pouco espaço e terem o aval dos proprietários vizinhos. Em certa ocasião, um dos fiscais do dia confirmou a versão de Gerson: "Ele não dá trabalha. Só ocupa o lado dele da rua". A ação da Prefeitura, do poder, do Estado é uma ação que não pára nunca. Ordenam o uso do solo, que se “desordena" e passa a ser ordenado de novo, num vai-e-vem infinito. Há pouco tempo atrás concluiu a reforma da Rua do Cabeça e outros becos e travessas da Avenida Sete de Setembro, para ali instalarem os muitos ambulantes que re-apareceram após a reforma do comércio ambulatório da Avenida Sete nos anos 1990, e várias outras que se seguiram depois. "Os peixes estão agora no Dois de Julho, mas vão tirar todo mundo da rua. Vão fazer uma peixaria".

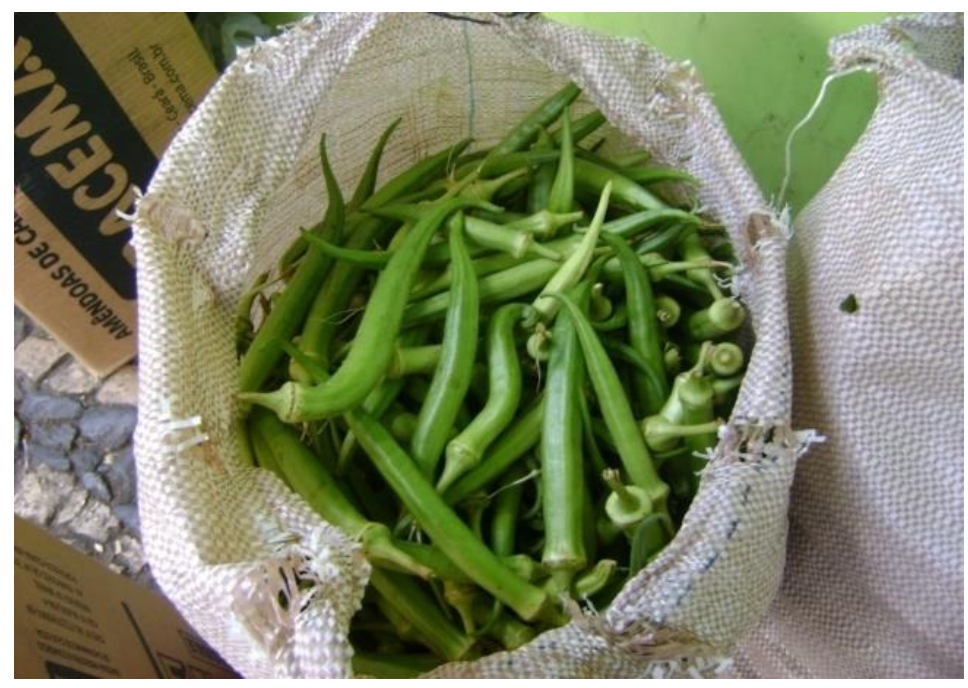

Fotografia de Urpi Montoya, 2013.

Gerson nasceu em Maraú. Nos anos 1950 veio para Salvador, com 14 anos. Mora no Lobato. Conheci-o um dia em que estava sentada numa das padarias da Rua do Forte de São Pedro, fazendo trabalho de campo sobre os usos da Avenida Sete. Nessa manhã entrou um homem falante, bem à vontade com o espaço, trocando palavras com a 
mulher do caixa. Perguntei a ela quem era. "É o Gerson, do camarão, fica aqui do lado". Assim eu me aproximei e fui, desde o início, muito bem recepcionada por ele. Nossa primeira conversa foi sobre a espécie de árvores da rua. "São otizeiro!”. Foi o único que soube responder à minha curiosidade. Em outra oportunidade me disse "eu tenho estudo, viu? Eu era menino prodígio. Trabalhei nos correios e telégrafos. Depois fui para o exército".

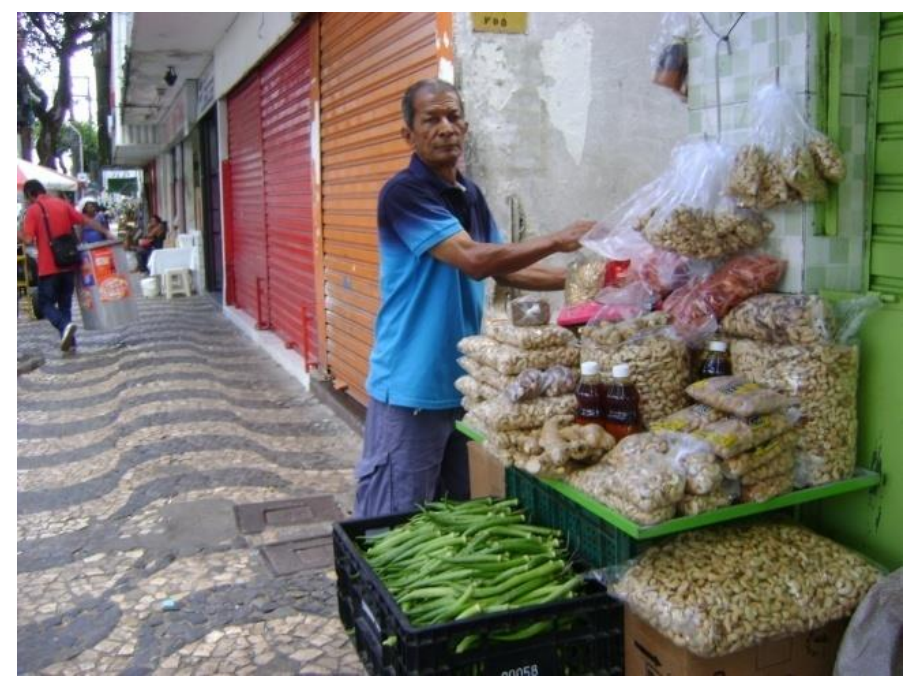

Fotografia de Urpi Montoya, 2013.

\section{A “caverna" de Zé}

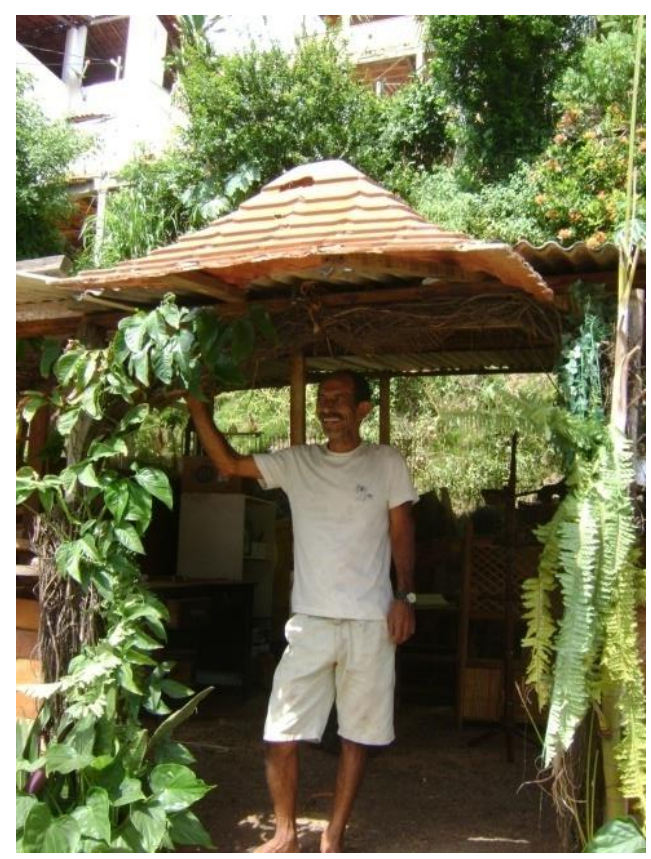

Fotografia de Urpi Montoya, 2013. 
Este é Zé, simpático e sorridente marceneiro, na frente de seu estabelecimento de "comércio de madeira reciclada", como ele gosta de dizer. Quando as fotos foram feitas, no ano de 2013, ele ainda não tinha colocado o nome de sua loja "Zé do pau". Em 2014, se arrependeu e só deixou o “Zé”.

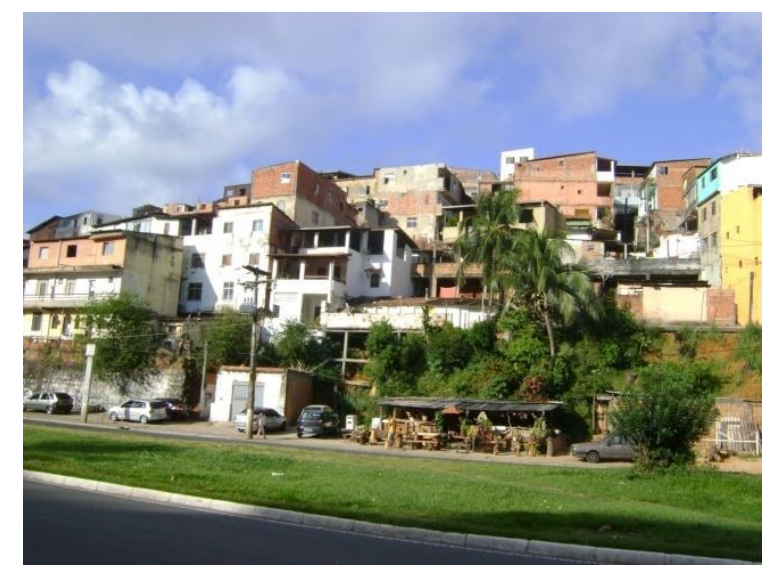

Fotografia de Urpi Montoya, 2013.

Seu comércio fica na Avenida Garibaldi ou, desde outro ponto de referência, no pé do morro da Vila Matos. Ele está há três anos no local. Já teve seu comércio de madeira e reciclagem em vários lugares da cidade. Cada vez que passava por aqui, olhava e achava que seria um local bom para seu ramo.

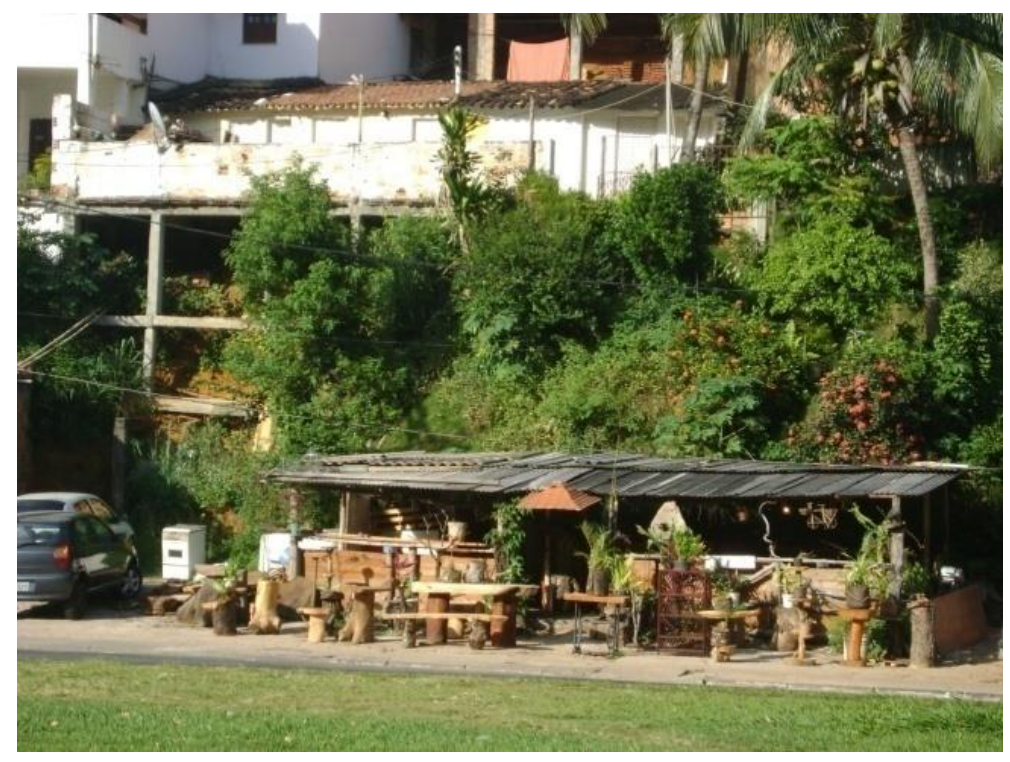

Fotografia de Urpi Montoya, 2013. 
Um dia, foi falar com a casa logo em cima do terreno que lhe interessava. Era a casa branca de Dona Dalva. Pediu para lhe alugar o mato de baixo, que ele limparia e colocaria uma venda, tudo direitinho. Dona Dalva topou alugar a mata em baixo da casa dela. "Eu limpei, botei duas telhas Eternit. Comecei sem água, sem luz, sem banheiro".

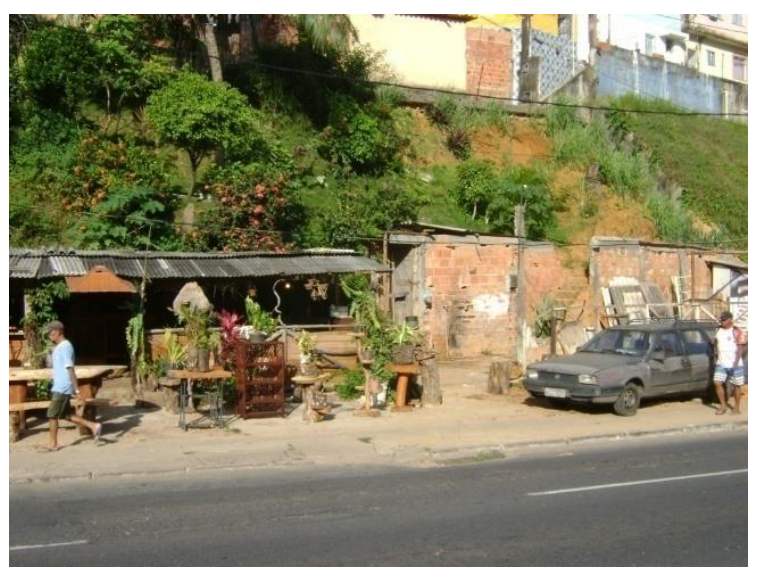

Fotografia de Urpi Montoya, 2013.

Há pouco tempo atrás, seguindo o exemplo de Gerson, os filhos de Dona Dalva construíram casinhas do lado dele, "sem alvará, sem nada", diz Zé, "então, veio a Sucom e demoliu tudo. Mais de 20.000 reais perdidos". Os fiscais só concordaram em deixar um muro "para proteger o terreno".

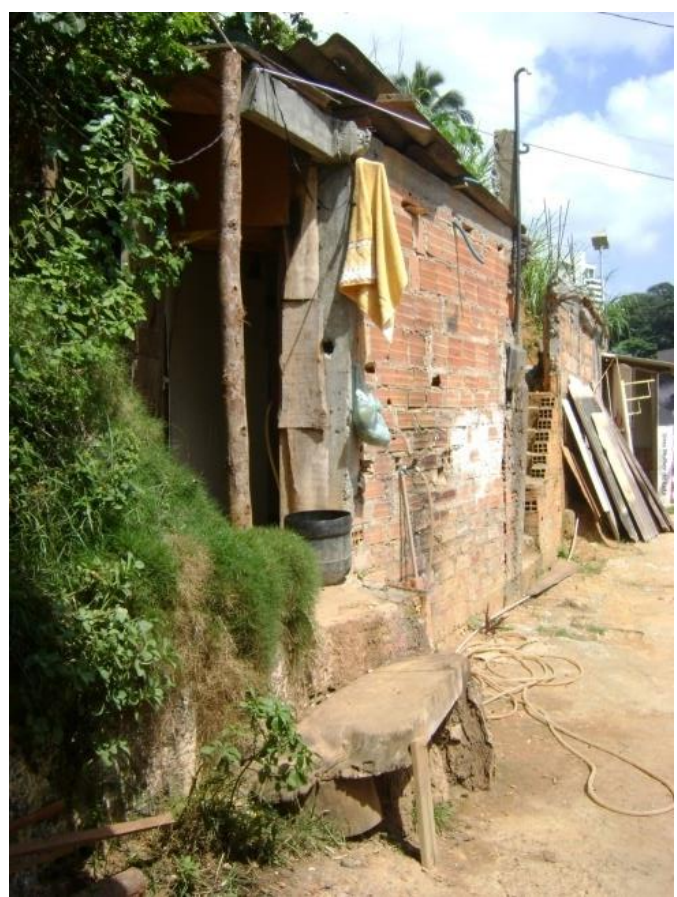

Fotografia de Urpi Montoya, 2013. 
Um dia, Gerson viu que entre o muro e o terreno havia um pequeno espaço, de menos de 2 metros de largura. Colocou um Eternit como teto e uma porta. E voilà! é o quartinho dele ou, como diz bem-humorado e informado, "a caverna de Bin Laden".

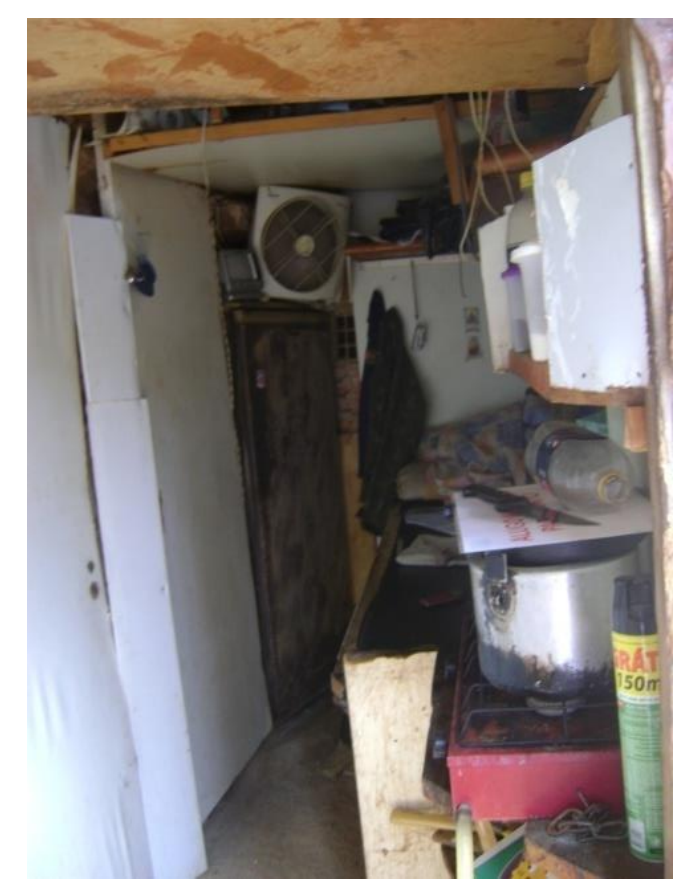

Fotografia de Urpi Montoya, 2013.

Nesse minúsculo espaço, colocou tábuas debaixo do Eternit e nos lados da ladeira. Lá dentro, tem uma mesa que funciona como cama (em branco), tem ventilador para os dias quentes, uma TV pequenininha, uma geladeira velha para guardar comida e água gelada e um fogãozinho de duas bocas para preparar suas refeições (em vermelho).

Ele tem sua casa no Engenho Velho de Brotas. Sua mulher é costureira e mora lá. Mas ele gosta de mato, silêncio, natureza. Às vezes ele vai lá. Outras, ele fica em sua caverna. Tem seu carro velho para pegar troncos de árvores e fazer seu trabalho ali. Pergunto se a casinha é dele. "É e não é. Não sei, vou ficando", responde sorrindo. Ele diz que a Sucom diz que pode ficar, desde que não construa nem bote paredes, nem invada a calçada. 


\section{Três leituras teóricas destes dois micro-espaços.}

Uma primeira leitura destes micro-espaços à luz da teoria lefebvriana consiste em entendê-los como espaços diferenciais que emergem no espaço abstrato pela fratura provocada nele ao serem incorporadas diferenças.

Lefebvre concebeu o espaço abstrato como o espaço próprio do capitalismo, isto é, um espaço cujas características refletem e permitem a reprodução das relações de produção próprias do capitalismo. Um espaço que se gerou num longo processo, entre os séculos XVI e $\mathrm{XX}^{5}$. Um espaço instrumento da burguesia, que possibilita a produção e circulação da mercadoria. Mas, talvez a característica mais importante do espaço abstrato seja a de ser o espaço do poder do Estado, um poder que, por sua vez, se sustenta na autoridade sobre o espaço ${ }^{6}$. O Estado domina o espaço o que significa que ele deve suprimir violentamente qualquer diferença sob alegações ideológicas de ordem, racionalidade, higiene, beleza, segurança nacional, proteção à natureza, etc. ${ }^{7}$. As diferenças são suprimidas mediante leis, códigos, normas, mandamentos, preceitos, regras escritas em papéis ${ }^{8}$ que determinam previamente os usos do espaço ${ }^{9}$. Os atores, usuários, "homens ordinários", têm de se adaptar às normas previamente fixadas. Como o Estado serve ao capitalismo, as normas e códigos respondem a uma concepção de ordem, racionalidade e higiene próprias da lógica capitalista que separa o lazer de casa, o trabalho de prazer, a natureza da alimentação, a locomoção das relações, e assim sucessivamente.

Entretanto, as diferenças reprimidas pelo espaço abstrato criado pelo capitalismo e pelo Estado se mantêm, existem, resistem, emergem em outro tipo espaço. Onde? De preferência, longe das vistas do espaço normatizado pelo Estado, isto é, nas periferias.

\footnotetext{
5 “O aparecimento e a posta em forma do espaço abstrato não têm uma data. Não são nem eventos nem instituições definidas e, não obstante, ao final do século XX, estão ali” (Lefebvre, 2000: 334)

6 "Todo Estado nasce da violência e o poder estático não persiste mais do que pela violência exercida sobre um espaço" (Lefebvre, 2000: 323)

7 "Espaço onde a violência se cobre de racionalidade e a racionalidade unificadora justifica a violência. De tal forma que, a homogeneização não aparece como tal, mas através de metáforas como o "consenso", a democracia parlamentar, a hegemonia, a razão de Estado" (Lefebvre, 2000: 325)

8 "Neste espaço e sobre ele tudo se declara: se diz, se escreve. Enquanto que há pouco a dizer, muito menos a viver. O vivido é esmagado. O concebido o leva. O histórico se vive como nostalgia e a natureza como lamentação" (Lefebvre, 2000: 63)

9 "Cada espaço foi colocado antes da vinda do ator /.../ que tenta se apropriar desse espaço. Esta existência pré-suposta condiciona a presença, a ação, o discurso desse 'sujeito', a competência e a performance: e, não obstante, sua presença, sua ação, seu discurso a negam supondo-a /.../ prática espacial determinada por ela: a um uso coletivo e individual" (Lefebvre, 2000: 70)
} 
Mas, o espaço diferencial emerge também em pleno centro normatizado, até nos espaços ditos nobres. É claro que em tempos de espaço-mercadoria, o espaço é um luxo, principalmente no centro, e as diferenças emergentes só podem ocupar micro-espaços. Eis o porquê do minúsculo ponto de Gerson e a minúscula caverna de Zé, localizadas no coração do espaço abstrato, isto é, codificado e vigiado pelo poder do Estado.

Se as diferenças persistem no espaço abstrato, então, ele é homogêneo apenas em aparência ${ }^{10}$. De fato, o que temos é o espaço abstrato contendo em seu interior o espaço diferencial, pois são as próprias contradições do primeiro que geram o segundo: as reduções, manipulações, funcionalismos, pressões suscitam, ressuscitam seu oposto, isto é, necessidades, sonhos, vontades outras, diferentes. "De sorte que, o espaço abstrato, apesar de sua negatividade, engendra um novo espaço que levará o nome de espaço diferencial", escreveu Lefebvre (2000: 64).

O espaço diferencial é, então, um espaço produzido pelas diferenças, mas principalmente, para as diferenças. É o espaço onde emerge aquilo que é negado, que o espaço abstrato gostaria que não existisse: as multifuncionalidades, as relações, as negociações informais, o prazer de trabalhar com alegria. Não é um complemento do espaço abstrato, pelo contrário, ele é gerado pelas contradições do espaço abstrato ${ }^{11}$. Gerson e Zé preferem seus minúsculos espaços produzidos por eles à formalização de se cadastrar e ter de se adequar aos espaços formais e abstratos que o sistema constantemente concebe e constrói (feiras ordenadas, zonas comerciais delimitadas). Uma leitura economicista poderia afirmar que estamos aqui diante de espaços capitalistas informais, de micro-empresários "expertos" criando um espaço para sua mercadoria, sem ter de pagar impostos. A meu ver, trata-se de dois homens lutando por fraturar o espaço abstrato, tentando fazer caber nele as diferenças, as particularidades de cada trabalhador querendo sobreviver e viver a seu modo ${ }^{12}$.

\footnotetext{
10 “O espaço abstrato não é homogêneo; tem a homogeneidade como meta, sentido, 'objetivo'. O impõe. Nele mesmo, é plural" (Lefebvre, 2000: 330). "Não há, portanto, de um lado espaço global (concebido) e de outro espaço fragmentado (vivido) como poderia haver um copo intato aqui e um copo ou espelho quebrado lá. O espaço "é" ao mesmo tempo total e quebrado, global e fraturado. Da mesma forma que é ao mesmo tempo concebido, percebido, vivido" (Lefebvre, 2000: 411).

11 "As contradições do espaço 'expressam' conflitos de interesses e forças sócio-políticas; mas estes conflitos só têm efeito e lugar no espaço, tornando-se contradições do espaço.” (Lefebvre, 2000: 421)

12 "O espaço se torna a questão principal das lutas e ações visando um objetivo. Nunca deixou de ser lugar de recursos, meio onde se desenvolvem as estratégias, mas se torna algo mais do que teatro, cena indiferente, quadro de atos /.../ Medium? Meio? Intermediário? Sim, mas de menos em menos neutro, de mais em mais ativo, ao mesmo tempo como instrumento e objetivo, como meio e como fim." (Lefebvre, 2000: 471, 472)
} 
A produção dos espaços diferenciais tem uma longa história. No caso das Américas, esta história começa no mesmo dia em que nasceram as cidades das letras, tão brilhantemente entendidas pelo escritor uruguaio Angel Rama (1985). Segundo Rama, as cidades latino-americanas foram "um parto da inteligência", de uma elite renascentista-barroca que quis transportar a ordem social hierárquica para o espaço, criando uma nova distribuição geométrica e racionalizadora do espaço. Não cabia, nessas muitas novas cidades fundadas no século XVI, pelo menos no plano, nenhuma individualidade, nenhuma imaginação diferencial, nenhuma invenção local. Mas, desde o mesmo dia de sua fundação, a cidade letrada teve de conviver com outra cidade em seu interior: a cidade vivida, isto é, usada, percorrida, que se fazia no dia-a-dia relacionando pessoas, conectando espaços, negociando regras e signos. Ao inventar por falta de espaço para eles, os habitantes excluídos do mundo das letras e da cidade letrada produziram e produzem diferenças, diferem e, com elas, produziram e produzem o urbano. "O urbano é a obsessão daqueles que vivem na carência, na pobreza, na frustração dos possíveis que permanecem como sendo apenas possíveis", escreveu Lefebvre em $O$ direito à cidade (1969: 93).

Como vimos, as diferenças fraturam o espaço abstrato, criando espaços diferenciais. Quanto maiores eles forem, mais o urbano está vivo numa cidade, pois o urbano nada mais é do que "uma diferença ou sobretudo um conjunto de diferenças" (Lefebvre, 1991: 78), ele é a própria "liberdade de produzir diferenças (de diferir e inventar o que difere)" (Lefebvre, 2002: 158). Então, talvez com excesso de otimismo, eu vejo nestes micro-espaços diferenciais, o urbano sendo criado. É a diferença dando lugar a relações. Tanto Gerson quanto Zé costumam pedir aos fregueses mais conhecidos e sem pressa para sentarem, descansarem, conversarem. É tão gratificante constatar o quanto as coações empreendidas pela lógica da racionalidade, ordem, separação, estética e visual, o quanto as normas e códigos da cidade letrada não dão conta de apagar o urbano que flui na cidade. A Prefeitura e a Sucom, mesmo querendo, não conseguem esmagar os usos diferenciais. Assim, apesar de todo o esforço e política para criar um espaço repressivo, a vida reaparece, ela se impõe, como aquelas plantas que, contra todas as perspectivas e prognósticos, crescem e florescem no meio do cimento. É a recusa da vida em ser contida, da qual nos fala o antropólogo britânico Tim Ingold: 
A sociedade moderna, é claro, tem aversão ao caos. Mas por mais que ela tenha tentado, através da engenharia, construir um mundo material à altura das suas expectativas - ou seja, um mundo de objetos discretos e bem ordenados -, suas aspirações são constantemente frustradas pela recusa da vida em ser contida. (Ingold, 2012: 37)

A vitalidade das coisas e, entre elas, das cidades, reside precisamente no fato delas não serem objetos - por definição, inertes, fixos. No pensamento de Ingold, o oposto dos objetos são as coisas, que estão em constante movimento, processo, fluxos, transformação. As coisas têm vida: as pedras inertes que erodem; as pipas estáticas que ao ar voam; os prédios fixos cujas paredes sofrem a infiltração de água; os potes de cerâmica que se quebram; o asfalto que se racha, são alguns exemplos dados por Ingold para falar dessa vida que se impõe. Acho que os casos narrados nos falam exatamente disso: da vida que se impõe, do urbano que se impõe.

Uma segunda leitura que faço dos dois micro-espaços descritos nestas páginas diz respeito ao potencial político deles. Parece-me que não estamos diante de espaços modificados ou espaços cujos usos parodiam outros espaços, mas diante de verdadeiros espaços produzidos, pois respondem e correspondem às necessidades daqueles que os construíram e usam. Nesse sentido, seriam, pois, espaços apropriados, desde que entendamos por "apropriação" o que Lefebvre sugeriu quando escreveu: "de um espaço natural modificado para servir às necessidades e possibilidades de um grupo, podemos dizer que este grupo se apropriou dele" (Lefebvre, 2000: 192). Assim, ele entendeu por apropriação as práticas que modificam um espaço natural, criando um espaço outro que, em função de ter sido produzido pelas próprias necessidades do grupo, revertendo, portanto, o mundo pelo avesso. As apropriações são revolucionárias.

Aos espaços apropriados, Lefebvre opunha os espaços contornados, cuja característica essencial era não serem novos espaços, mas apenas espaços cujos usos iniciais foram modificados. Sem criar um outro espaço, as práticas que apenas contornam se re-apropriam de um espaço já criado e, pela sua vacância, dão-lhe um outro uso que não é o primeiro. Lefebvre nos propôs mais um conceito no final de seu livro A produção do espaço: os contra-espaços, que seriam aqueles que respondem, reagem, parodiam e, justamente por isso, não conseguiriam sair do espaço produzido pelo poder.

Quando uma população se opõe a um projeto de estrada ou extensão urbana, quando ela reclama 'equipamentos', lugares vazios para jogos e encontros, percebemos 
como um contra-espaço se introduz na realidade espacial /.../ É claro, acontece também, que o contra-espaço e o contra-projeto simulam o espaço existente, o parodiam, o demarcam sem sair dele. (Lefebvre, 2000: 440)

Foucault (1967), antes de Lefebvre, tinha proposto entender os contra-espaços como heterotopias, ou seja, lugares onde se contesta e inverte o constituído, porém lugares que não deixam de estar conectados com os outros lugares, a pesar de serem completamente diferentes deles. As clínicas de repouso, prisões, cemitérios, museus, bibliotecas, feiras, bordéis, colônias, navios, têm comum o de servir de ilusão ou compensação em relação aos espaços instituídos - ou isotopias (lugares do mesmo). Sem sair do sistema, o complementam criando a ilusão de um espaço outro, quando, de fato, não o são. A diferença entre as heterotopias ou contra-espaços e os espaços apropriados é que os últimos são efetivamente produzidos atendendo as necessidades, sonhos, vontades e diferenças do próprio grupo produtor, que é ao mesmo tempo seu usuário.

Nesse sentido, os contra-espaços nos lembram as artes de fazer, de Michel de Certeau, que não são criações, produções, mas maneiras de empregar o que já foi produzido por outrem. A não-produção advém precisamente da ausência de um espaço próprio diante do qual, só restariam as astúcias táticas, isto é, a inventividade, a bricolagem, as manobras na conjuntura (Certeau, 2009: 44). A invenção do cotidiano parece ser um texto que elogia a "lógica operatória cujos modelos remontam talvez às astúcias multimilenares dos peixes disfarçados ou dos insetos camuflados” (p.37), contudo, o próprio Certeau admite timidamente que o desvio da ordem não significa a sua mudança ${ }^{13}$. As astúcias milenares, os espaços contornados e os contra-espaços, assim, fazem parte integrante-integrada do sistema, quando o que deve ser buscado é a criação de novos espaços. Em A produção do espaço, Lefebvre nos incita a não nos iludirmos:

Uma revolução que não produz um espaço novo não vai até o final dela mesma; ela fracassa; ela não muda a vida; ela só modifica superestruturas ideológicas, instituições, aparelhos políticos. Uma transformação revolucionária se verifica na sua capacidade criadora de obras na vida cotidiana, na linguagem, no espaço. (Lefebvre, 2000: 66)

\footnotetext{
13 “A ordem efetiva das coisas é justamente aquilo que as táticas 'populares' desviam para fins próprios, sem a ilusão que mude proximamente" (Certeau, 2009: 83).
} 
Acho que nem o beco nem o pé do morro eram espaços já criados que Gerson e Zé teriam apenas reutilizado. Eles se apropriaram desses espaços-natureza e criaram outros. Essa é sua força.

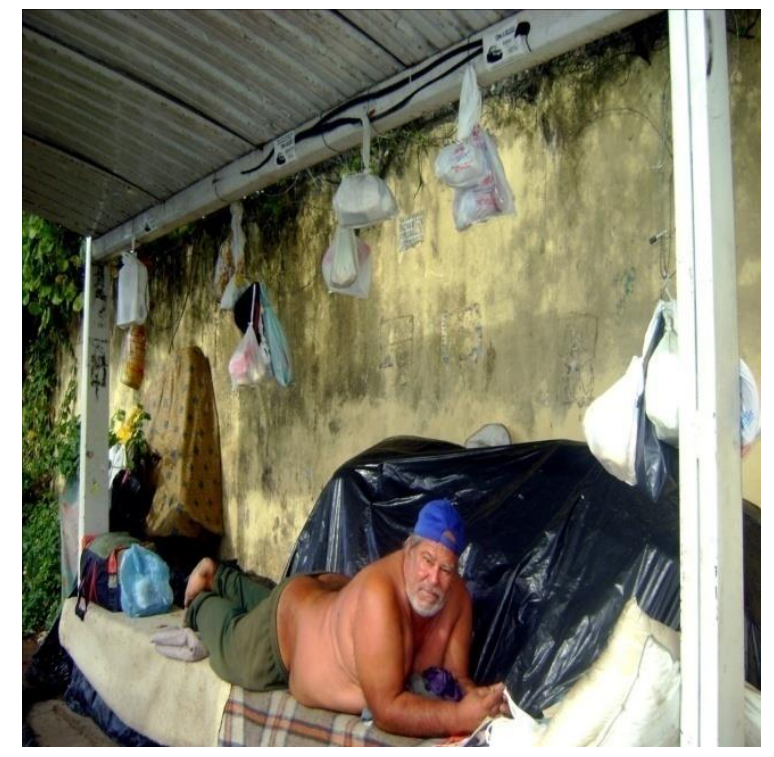

Fotografia de Mayu Montoya Costa, 2012.

Muito diferente do caso de Alberto, que, ao longo de 2012, no bairro de Stella Mares, fez de um ponto de ônibus pouquíssimo usado a sua casa. Ele não se apropriou desse espaço, mas se re-apropriou dele, fez do ponto um espaço contornado: essa foi sua fraqueza. Mesmo recebendo o apoio de muitos moradores que o alimentavam física e espiritualmente (pois lhe davam muitos livros e revistas que lia avidamente), um belo dia, ele foi retirado. Após meses vivendo no antigo ponto, ele não agüentou e, segundo fontes diversas, veio a falecer pouco depois.

A terceira leitura que proponho diz respeito ao valor do uso que esses microespaços (re)colocam em cena. Usar significa negociar algo com o Outro, pois meu uso só é possível se o uso que o Outro faz desse algo assim o permite. Gerson negocia com as proprietárias do beco para que elas não solicitem a sua remoção e para que o deixem ficar na porta do beco; negocia com os donos do comércio estabelecido, que são seus vizinhos (uma padaria, um comércio de bijuterias), para poder deixar diariamente seus balaios nos depósitos das lojas; negocia informalmente com os fiscais da Prefeitura para poder ficar, embora não saiba até quando ele conseguirá. Por sua vez, Zé negocia com Dona Dalva, a proprietária de cima, a quem ele adjudica a propriedade do terreno baldio 
de baixo; negocia informalmente com a Sucom ${ }^{14}$ para permanecer no local, seguindo as regras que lhe são colocadas.

Estas negociações para além da formalidade e o papel, a meu ver, des-sacralizam o que a cidade letrada sacralizou: a escrita, os códigos, normas, advogados, escreventes, contratos, títulos de propriedade, etc. Gerson e Zé não se importam com títulos, com papéis. O que está em jogo, para eles, é o valor de uso. Vão usando até quando der, se apossando precariamente, pois assim a saída, se vier - e nunca se descarta essa possibilidade -, será mais fácil e as perdas menores. Os defensores da legalidade, da regularização (muitos com excelentes intenções), esquecem que nenhuma grande transformação se faz pelas vias legais, seguindo as regras. Assim, o direito à cidade, que é o direito ao urbano, isto é, ao espaço diferencial, à diferença em suma, tem então que, necessariamente, transbordar o direito escrito, prescrito. É a relação entre pessoas e não a relação contratual a que tem de ser constantemente afirmada, buscada. Lefebvre assim o preconizava:

O urbano (a vida urbana, a vida da sociedade urbana) já implica uma substituição do contrato pelo costume. O direito contratual fixa os limites da troca e da reciprocidade na troca /.../ Ora, o uso, no urbano, compreende costumes e confere ao costume a precedência em relação ao contrato. O emprego dos objetos urbanos (essa calçada, essa rua, esse atalho, essa iluminação, etc.) é costumeiro, não contratual. (Lefebvre, 2002: 163)

O interessante é que as histórias de Gerson e Zé nos mostram precisamente a busca e o sucesso, pelo menos até o momento, na imposição de relações que são costumeiras, não contratuais.

\section{Palavras finais}

A obra de Lefebvre sobre o urbano e o espaço é extremamente rica. Ela nos oferece uma riquíssima grama de conceitos e nos sugere uma enorme agenda de pesquisa. Mas, principalmente, nos dota de um utopismo imprescindível para os dias de hoje, marcados pelo pragmatismo, conformismo e desencantamento. Salientamos de

\footnotetext{
${ }^{14}$ Superintendência de Controle e Ordenamento do Uso do solo - órgão criado em 1989, com a finalidade de Supervisionar, acompanhar, fiscalizar e planejar o cumprimento das normas relativas ao ordenamento do uso e ocupação do solo do Município de Salvador (http://www.sucom.ba.gov.br/index.php?page=10)
} 
partida que não entendemos a utopia como espaços irreais, conforme a concebera Foucault,

\begin{abstract}
Utopias são lugares sem uma localização real. São lugares que têm uma relação geral de analogia direta ou invertida com o espaço real da sociedade. É a própria sociedade aperfeiçoada, ou é o inverso da sociedade, mas em todo caso essas utopias são fundamentalmente, essencialmente, espaços irreais. (Foucault, 1984: 4).
\end{abstract}

Mais uma vez, recorremos a Lefebvre: para ele, utopia não é apenas o irreal ou a visão invertida do real, mas “o que não tem lugar e o procura” (Lefebvre, 2002: 157), ou seja, o que não tem espaço, mas quer tê-lo. A utopia é o possível que busca ser. E mais, é o possível que já faz parte do real: "o possível faz parte do real, lhe dá o sentido, ou seja, a direção e a orientação, a via aberta para o horizonte" (Lefebvre, 2002: 51). Este entendimento da utopia a coloca como a grande busca do pensamento crítico. Trata-se de entender o real para superá-lo a partir do possível contido nele. A crítica de esquerda, escreveu Lefebvre,

É aquela que tenta abrir a via do possível, explorar e balizar um terreno que não seja simplesmente aquele do 'real', do realizado, ocupado pelas forças econômicas, sociais e políticas existentes. É, portanto, uma crítica utópica, pois toma distância em relação ao real, sem, por isso, perdê-lo de vista. (2002: 20)

Buscar a utopia não é, pois, sonhar. Pelo contrário, é um trabalho muito real, de cavar a realidade e encontrar o possível escondido nela. Lamentavelmente, a pesquisa utópica ou o pensamento utópico não estão em voga em nossos tempos, dominados como estamos pelo reducionismo que reduz o real ao identificável ou classificável; que reduz ${ }^{15}$ o possível ao provável, repelindo o possível-impossível. Navegando na contracorrente, o que estas linhas se propuseram foi abrir espaço aos micro-espaços urbanos e à tentativa de lê-los para além da descrição etnográfica, enxergando neles, bem munidos teoricamente, elementos do possível capazes de construir e pensar uma outra cidade.

\title{
Referências
}

AGIER, Michel. Antropologia da cidade. Lugares, situações, movimentos. São Paulo: Terceiro Nome, 2011.

\footnotetext{
${ }^{15} \mathrm{O}$ reducionismo nada mais é do que a indiferença, ou seja, a incapacidade de entrever as diferenças e suas possibilidades (Lefebvre, 1970).
} 
BIASE, Alessia de. "Por uma postura antropológica de apreensão da cidade contemporânea". Redobra, N.10, Salvador, 2012.

CERTEAU, Michel. A invenção do cotidiano. 1. Artes de fazer. Petrópolis: Editora Vozes, edição 16, 2009 [1981].

FOUCAULT, Michel. De outros espaços (1967), conferência no Cercle d’Études Architecturales, 14 de março de 1967, in Architecture, Mouvement, Continuité, N.5, out. 1984, pp.46-49.Acessível em analobocrispi.files.wordpress.com/.../michelfoucaultheterot_carmela.pdf INGOLD, Tim. "Trazendo as coisas de volta à vida: emaranhados criativos num mundo de mundo de materiais". Horizontes antropológicos, Porto Alegre, ano 18, n. 37, p.25-44, jan./jun. 2012.

. "Anthropology is not ethnography”. British Academy (2008), 154, 69 - 92. Disponível em proc.britac.ac.uk/files/154p069.pdf

LEFEB VRE, Henri. Le manifeste différentialiste. Paris: Gallimard, 1970.

. O direito à cidade. São Paulo: Editora Moraes, 1991 [1969].

. A revolução urbana. Belo Horizonte: Editora UFMG, 2002 [1970].

. La production de l'espace. Paris: Anthropos, 4e. edition, 2000 [1974].

MASSEY, Doreen. Pelo espaço. Uma nova política da espacialidade. Rio de Janeiro: Bertrand Brasil, $3^{\mathrm{a}}$ ed., 2012.

RAMA, Angel. A Cidade das Letras. São Paulo: Editora Brasiliense, 1985.

SÉGAUD, Françoise. Anthropologie de l'espace. Habiter, fonder, distribuer, transformer. Paris: Armand Colin, 2010.

SOJA, Edward. Geografias pós-modernas. A reafirmação do espaço na teoria social crítica. Rio de Janeiro: Zahar, 1993.

Recebido em: 27/09/2014

Aprovado em: 10/11/2014 